\title{
IDIOGRAFICKÁ DIAGNOSTIKA
}

\author{
JIŘÍ MAREŠ \\ Univerzita Karlova v Praze, Lékařská fakulta v Hradci Králové
}

\begin{abstract}
Přehledová studie upozorňuje, že se od dob W. Windelbanda proměnil pohled na nomotetický a idiografický př́stup ve výzkumu i diagnostice. Připomíná, že lze rozlišit užší pojem psychologické testování, jež staví na standardizovaných nástrojích, a širší pojem psychologické hodnocení, psychologická diagnostika opírající se o klinický př́stup. S oporou o práci Haynese et al. (2009) pak definuje idiografickou diagnostiku a ukazuje, že jde o proud, který se promyšleně snaží individualizovat psychologickou diagnostiku. Těžiště přehledové studie spočívá v ukázkách, jak se tyto snahy prosazují při diagnostice individuální kvality života lidí. Míru individualizace diagnostický nástrojů lze odstupňovat - podle O’Boyla et al. (2007) existuje šest stupňů. Studie na prŕkladu diagnostického nástroje SQLP - Subjective Quality of Life Profile (Dazord et al. 1995, 1998) ilustruje konkrétní podobu individualizace. V závěru jsou shrnuty výhody a nevýhody individualizovaných diagnostických nástrojů.
\end{abstract}

Klíčová slova: idiografická diagnostika, individualizovaná diagnostika, individuální kvalita života Key words: idiographic assessment, individualized assessment, individual quality of life

\section{Úvod}

Je tomu více než sto let, co W. Windelband zavedl metodologické rozlišení vědních oborů na nomotetické a idiografické (Windelband, 1967). Nomotetické vědy (podle něj empirické př́rodní vědy typu fyziky, chemie, biologie, ale i psychologie) pátrají po základních principech, snaží se objevit a přesně definovat obecně platné zákonitosti. Oproti tomu idiografické vědy (např. duchovní vědy typu historie) se zajímají o jedinečné jevy, časově omezené skutečnosti, o specifické případy v historicky určité době. Principem dělení na nomotetický a idiografický př́stup je podle Windelbanda cíl poznání, nikoli samotný charakter dané vědy, nebot' stejné předměty se mohou stát předmětem nomotetického i idiografického výzkumu (Windelband, 1967, s. 529). Z hlediska utility jsou podle něj oba př́istupy rovnocenné.

Během desítek let se ve společenských vědách poněkud zapomnělo na původní Windelbandovo pojetí a v běžné praxi vykrystalizovalo zjednodušené dělení celých vědních oborů na tvrdé (nomotetické) a měkké (idiografické). Obdobné zjednodušení se přeneslo i na úroveň samotných oborů. Uvnitř některých oborů, včetně psychologie, jsme svědky dělení výzkumných a diagnostických př́stupů na kvantitativní (nomotetické) a kvalitativní (idiografické). Je váhavě se v některých kruzích připouští, že existuje i prŕstup smíšený (podrobnosti viz Tashakkori, Teddlie, 2003).

V americké psychologii se v posledních letech setkáváme s rozlišením psychologického testování (psychological testing) a psychologického zhodnocení, psychologické diagnostiky (psychological assessment). Psychologické testování je pojem užší a rozumí se jím relativně jasný, nekomplikovaný proces, při němž administrujeme standardizovaný nástroj, abychom jeho prostřednictvím získali specifický skór. S takto získaným skórem dále pracujeme, abychom normativním, nomotetickým způsobem dospěli k určitému závěru o daném jedinci. Oproti tomu šiřeji chápaná psychologická diagnostika staví na klinickém př́stupu, $\mathrm{v}$ jehož rámci psycholog vychází z různých testových skórů (tedy z údajů, jež získal mnoha testovými nástroji), ale navíc bere v úvahu anamnestická data, informace z jiných zdrojů, čerpá z pozorování klientova chování, z odpovědí, které mu klient dává při rozhovoru, přihlíží ke kontextu jedincova života. Zatímco při nomotetickém př́istupu 
lze jedincův skór $10 \mathrm{v}$ aritmetickém subtestu Wechslerova inteligenčním testu pro dospělé interpretovat tak, že jedinec má průměrné aritmetické schopnosti, při idiografické diagnostice (idiographic assessment) můžeme tentýž skór interpretovat mnoha různými způsoby. Např. u pacienta krátce po úrazu hlavy může tento skór svědčit o náhlém zúžení rozsahu jeho pozornosti a zhoršení jeho schopnosti pracovat s numerickými informacemi. U druhého pacienta, který už absolvoval léčbu po úrazu hlavy, a psycholog se soustředil na odstraňování poruch jeho pozornosti, naopak tentýž skór dokládá výrazné zlepšení pacientových kognitivních funkcí. U třetího, velmi inteligentního klienta, může být tento skór interpretován jako doklad prožívané úzkosti a deprese, které zhoršují jeho schopnost plně se soustředit na zadaný úkol (volně podle Meyer, Finn, Eyde et al., 2001, s. 143).

Po tomto obecném úvodu můžeme přejít k podrobnějšímu výkladu. Cílem našeho př́́pěvku je: 1. upozornit na snahy individualizovat psychologickou diagnostiku, 2. přiblížit pojem idiografická diagnostika, 3. ilustrovat tyto snahy př́íklady z výzkumů kvality života, 4 . shrnout výhody a nevýhody individualizované diagnostiky.

\section{Idiografická diagnostika}

Tradiční nomotetická diagnostika, která se opírá o standardizované testy a dotazníky, se zajímá spíše o rozdíly mezi lidmi. Můžeme si však stanovit jiný cíl: porozumět konkrétnímu jedinci samotnému, jeho intra-individuálním charakteristikám nebo - řečeno s Cervonem et al. (2008) - jeho ,architektuře osobnosti“. Může nás také zajímat dynamický pohled, tedy míra proměnlivosti jeho charakteristik v čase, jeho intra-individuální variabilita (Caldwell et al., 2008). Pak ovšem musíme diagnostiku individualizovat.

Obecná úvaha říká, že snaha individualizovat diagnostiku se může ubírat čtyřmi cestami (Haynes et al., 2009, s. 180):

a) individualizujeme celou diagnostickou strategii (např. zkonstruujeme úplně nové, velmi specifické nástroje a použijeme je specifickým způsobem)

b) individualizujeme data (budeme stavět na kasuistikách, na unikátních př́padech)

c) z tradičních nomotetických, standardizovaných nástrojů vybereme jen určité části, např. bloky položek a ty zadáme specifické skupině respondentů

d) tradiční standardizované nástroje modifikujeme; zařadíme části, které dovolí individualizaci odpovídání (napřr. přidáme blok položek, který se zajímá o osobní cíle konkrétního respondenta).

Pro tento nový směr se v psychologii razí označení idiografické diagnostikování (idiographic assessment). Pro psychology v praxi jsou zajímavé varianty uvedené pod písmeny c) a d). Právě těmto dvěma možnostem je věnována přehledová metodologická studie Haynese et al. (2009). Autor v ní konstatuje, že idiografické diagnostikování se dá vymezovat různými způsoby a uvádí tyto definice (Haynes et al., s. 180):

a) jde o použití postupů, jimiž lze dospět k idiografické informaci nebo k obsahu individuálního př́padu, což může být využito při formulování kasuistiky (Barton et al., 2005)

b) jde o individualizovanou metodu získávání i zpracování dat, jež se zaměřuje na vztahy mezi situacemi (definovanými samotným jedincem) a jedincovým chováním; postup umožňuje poskytnout individuálně specifická vodítka pro terapeutické působení na jedince (Claes at al., 2004) 
c) jde o metody, nástroje, měřící postupy a situační kontexty, jež jsou určeny specifickému jedinci (Hayes, O’Brien, 2000)

d) jde o diagnostický postup pro stanovení diagnózy a pro terapii individuálních př́padů; jeho cílem je dospět k predikci a usnadnit praktické rozhodování ve speciálních př́ípadech (McFall, 2005)

e) jde o konstrukty měření nebo o specificky definované cíle (definované v pojmech jedincova chování) či situační proměnné, které jsou relevantní pro daného jedince; mohou posloužit jako indikátory kauzálních vztahů a/nebo indikátory proměn jedince v čase (Mumma, 2001)

f) jde o zaměření se na intraindividuální organizaci jedincova chování, tedy na specifické podoby variability ve vztazích „situace-jedincovo chování“ a to v průběhu času (Shoda et al., 1994).

Haynes se spolupracovníky (2009, s. 180) navrhuje tuto souhrnnou definici idiografického diagnostikování: jde o měření proměnných a funkčních vztahů, které staví na výběru, který provedl sám jedinec; nebo se měření odvozuje od specifických diagnostických podnětů anebo z kontextů, jež jsou, ,šity na míru“ danému jedince. Cílem je, aby postup co nejlépe vystihl zvláštnosti daného konkrétního jedince.

Definice idiografického diagnostikování má tedy některé obecné znaky:

a) alespoň některé části diagnostického nástroje jsou určeny $\mathrm{k}$ tom, aby byly citlivé na zvláštnosti daného respondenta a současně pro něj klíčové

b) diagnostický nástroj nebo diagnostická strategie jsou bud' větvené nebo alespoň zčásti nestandardizované; v některých částech se diagnostický nástroj či použitá strategie liší respondent od respondenta

c) některé části diagnostického nástroje nebo diagnostické strategie (např. schéma diagnostického nástroje) naopak mohou být standardizovány (Haynes et al., s. 180).

\section{Příklady z výzkumů individuální kvality života}

V medicíně, v klinické psychologii, v psychologii zdraví se začíná zkoumat individuální kvalita života lidí - Individual Quality of Life, zkráceně bud' IQOL nebo iQOL. Obvykle se jí rozumí jedincův svébytný pohled na vlastní život, tedy individuálně specifický způsob vnímání a prožívání vlastního života, porozumění vlastnímu životu a hodnocení svého života. Jedinec má svůj osobní vztahový rámec, vjehož kontextu vnímá své životní zkušenosti, své místo v životě - jak podle individuálního systému hodnot, tak i podle hodnot té kultury, v níž žije. Má své vlastní životní cíle, zájmy, očekávání, strategie svého snažení. Posuzuje svůj aktuální život vzhledem k reálně dosažitelné úrovni i ke svému ideálu. Vybírá a posuzuje především ty oblasti kvality života, které on považuje za důležité pro svůj život (modifikovaně podle Dupuis et al., 2001; Dempster, Donnelly, 2000; Carr, Higginson, 2001). Právě zde se s výhodou uplatňuje individualizovaná diagnostika (podrobnosti viz Mareš, 2008).

V laické veřejnosti (a zčásti i v odborné veřejnosti) panuje představa, že diagnostické nástroje jsou bud' individuální nebo hromadné. Realita je ovšem jiná, nebot' nástroje lze odstupňovat podle míry individualizace, tedy podle stupňů volnosti, který poskytují respondentovi. Základní třídění navrhli O’Boyle et al. (2007) a z jejich práce vychází tab. 1. 
Tab. 1 Různé stupně individualizace u nástrojů, které zjišt'ují kvalitu života (modifikovaně podle O'Boyle et al., 2007, s. 225-234)

\begin{tabular}{|c|c|c|}
\hline $\begin{array}{c}\text { výběr oblastí kvality života } \\
\text { provádí }\end{array}$ & $\begin{array}{c}\text { elaborování oblastí kvality života } \\
\text { provádí }\end{array}$ & $\begin{array}{c}\text { přidělování váhy oblastem } \\
\text { kvality života provádí }\end{array}$ \\
\hline badatel & - & badatel \\
\hline badatel & - & respondent \\
\hline badatel & respondent & - \\
\hline badatel & respondent & respondent \\
\hline respondent & respondent & respondent (implicitně) \\
\hline respondent & respondent & respondent (explicitně) \\
\hline
\end{tabular}

Obecné tř́dění však neposkytuje zájemcům představu o tom, jak takový individualizovaný diagnostický nástroj může vypadat. Podívejme se tedy na konkrétní príklad.

Skupina francouzských badatelů (Dazord et al., 1995, 1998) navrhla a ověřila nástroj, který nazvala SQLP (Subjective Quality of Life Profile). Kromě definování různých oblastí kvality života a přidělování subjektivní váhy ji zajímalo, zda jedinec předpokládá, že v některé oblasti kvality života u něj dojde k nějaké změně; zjišt’ují tedy očekávání změny vůbec. Postup, jak se individualizovaná diagnostika provádí, přibližuje tab.2.

Tab. 2 SQLP - profil subjektivní kvality života

\begin{tabular}{|c|c|c|c|}
\hline Etapy posuzování & Úkol pro respondenta & $\begin{array}{l}\text { Zkoumaný aspekt } \\
\text { individuální kvality } \\
\text { života }\end{array}$ & Poznámka \\
\hline 1. krok & $\begin{array}{l}\text { Pročíst si základní na- } \\
\text { bídku } 27 \text { položek, které } \\
\text { charakterizují různé } \\
\text { oblasti kvality života. }\end{array}$ & \multirow{3}{*}{$\begin{array}{l}\text { Jedincem vnímané oblasti } \\
\text { vlastního života, které } \\
\text { právě pro něj konstituují } \\
\text { kvalitu života. }\end{array}$} & \multirow{3}{*}{$\begin{array}{l}\text { Respondent se vyjadřuje } \\
\text { k tomu, jak významné } \\
\text { jsou v dané etapě jeho } \\
\text { života jednotlivé oblasti } \\
\text { kvality život. Zjišt'uje se } \\
\text { tím aktuální hierarchie } \\
\text { oblastí života. }\end{array}$} \\
\hline 2. krok & $\begin{array}{l}\text { Z nabízené rozsáhlé data- } \\
\text { banky položek vybrat } \\
\text { další položky, které ne- } \\
\text { byly obsaženy v základní } \\
\text { nabídce } 27 \text { položek. }\end{array}$ & & \\
\hline 3. krok & $\begin{array}{l}\text { Pokud jedinec nenašel ani } \\
\text { ve druhém kroku to, co } \\
\text { považuje za důležitý } \\
\text { aspekt vlastního života, } \\
\text { mǔže doplnit jednu svou } \\
\text { položku, která vystihuje } \\
\text { to, co je pro něj aktuálně } \\
\text { závažné. }\end{array}$ & & \\
\hline 4. krok & $\begin{array}{l}\text { U všech položek, které } \\
\text { vznikly v krocích 1.-3. } \\
\text { posoudit jejich „objek- } \\
\text { tivní stav“, a to pomocí } \\
\text { 4stupňové škály. }\end{array}$ & $\begin{array}{l}\text { Jedincem vnímaný „,reál- } \\
\text { ný stav“ jeho kvality } \\
\text { života. }\end{array}$ & $\begin{array}{l}\text { Snaha přimět jedince, aby } \\
\text { se zamyslel nad tím, jak } \\
\text { vidí kvalitu jeho života } \\
\text { nezávislí posuzovatelé. }\end{array}$ \\
\hline 5. krok & $\begin{array}{l}\text { U všech položek, které } \\
\text { vznikly v krocích 1.-3. } \\
\text { uvést, nakolik se jedinci } \\
\text { daří je v životě naplňovat, } \\
\text { a to pomocí 5stupňové } \\
\text { škály. }\end{array}$ & $\begin{array}{l}\text { Míra spokojenosti s usku- } \\
\text { tečňováním, s naplňo- } \\
\text { váním jednotlivých ob- } \\
\text { lastí kvality života. }\end{array}$ & $\begin{array}{l}\text { Odhad míry naplňování, } \\
\text { uskutečňování jednotli- } \\
\text { vých aspektů kvality } \\
\text { života. }\end{array}$ \\
\hline
\end{tabular}




\begin{tabular}{|c|c|c|c|}
\hline 6. krok & $\begin{array}{l}\text { U všech položek, které } \\
\text { vznikly v krocích 1.-3. } \\
\text { posoudit jejich důležitost, } \\
\text { závažnost pro jedince, a } \\
\text { to pomocí 3stupňové } \\
\text { škály. }\end{array}$ & $\begin{array}{l}\text { Míra důležitosti, závaž- } \\
\text { nosti jednotlivých oblastí } \\
\text { kvality života pro daného } \\
\text { jedince. }\end{array}$ & \\
\hline 7. krok & $\begin{array}{l}\text { U všech položek, které } \\
\text { vznikly v krocích 1.-3. } \\
\text { posoudit, nakolik jedince } \\
\text { očekává, že v nejbližších } \\
\text { měsících u nich dojde ke } \\
\text { změně. Posuzování se } \\
\text { provádí pomocí 5stup- } \\
\text { ňové škály. }\end{array}$ & $\begin{array}{l}\text { Míra předpokládané změ- } \\
\text { ny u jednotlivých oblastí } \\
\text { kvality života z pohledu } \\
\text { daného jedince. }\end{array}$ & $\begin{array}{l}\text { Snaha přimět jedince, aby } \\
\text { se zamyslel, nakolik je } \\
\text { určitý aspekt kvality jeho } \\
\text { života měnlivý. }\end{array}$ \\
\hline 8. krok & $\begin{array}{l}\text { U všech položek, které } \\
\text { vznikly v krocích 1.-3. } \\
\text { posoudit, nakolik jedinec } \\
\text { považuje očekávanou } \\
\text { změnu za důležitou, zá- } \\
\text { važnou. Posuzování se } \\
\text { provádí pomocí 3stup- } \\
\text { ňové škály. }\end{array}$ & $\begin{array}{l}\text { Míra důležitosti před- } \\
\text { pokládané změny u jed- } \\
\text { notlivých oblastí kvality } \\
\text { života z pohledu daného } \\
\text { jedince. }\end{array}$ & $\begin{array}{l}\text { Snaha přimět jedince, aby } \\
\text { se zamyslel, nakolik je } \\
\text { určitý aspekt kvality jeho } \\
\text { života nejen měnlivý, ale } \\
\text { také, jak závažná změna } \\
\text { to pro něj může být. }\end{array}$ \\
\hline 9. krok & $\begin{array}{l}\text { Vyplnit některé další } \\
\text { položky, jež zjišt'ují glo- } \\
\text { bálnější pohled jedince na } \\
\text { současnou kvalitu života } \\
\text { a na jeho výhled do bu- } \\
\text { doucnosti. }\end{array}$ & 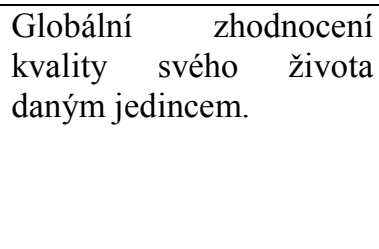 & \\
\hline
\end{tabular}

V zásadě lze říci, že Dazord a spolupracovníci neusilují o stanovení jakéhosi souhrnného indexu kvality života, ani vypočtení dílčích skórů pro jednotlivé oblasti kvality života. Spíše jim jde o jemnější vhled do způsobu, jímž respondent přemýšlí o své kvalitě života a jejích proměnách.

Po těchto př́ikladech už zbývá jen mínit výhody a nevýhody individualizované diagnostiky.

\section{Výhody individualizovaných nástrojů}

Naznačili jsme několik typových př́stupů $\mathrm{k}$ individualizované diagnostice. Nyní se pokusíme shrnout přednosti individualizovaných nástrojů:

a) čas a úsilí věnované jejich vývoji jsou srovnatelné s vývojem standardizovaných dotazníků

b) individualizované nástroje nabízejí unikátní pohled na intra-individuální charakteristiky a kontext života každého jedinečného individua

c) dovolují zachytit individuálně specifickou sestavu těch proměnných, kterých si jedinec sám nejvíce cení nebo mu nejvíce činí obtíže (individuální strukturu proměnných)

d) dovolují přiřadit každé nominované proměnné individuálně specifickou míru závažnosti (lze tak dospět k individuálně specifické hierarchii proměnných) 
e) dovolují přiřadit každé nominované proměnné individuálně specifickou míru jedincovy spokojenosti s danou proměnnou

f) některé metody umožňují posoudit perspektivní orientaci daného jedince (např. jeho životní cíle)

g) některé metody umožňují posoudit jedincem předpokládanou dynamiku změn (jeho osobní očekávání)

h) individualizované nástroje lépe motivují klienty ke spolupráci, nebot' se přizpůsobují jejich zvláštnostem; jedinec se nemusí vyjadřovat k tomu, co považuje pro svou situaci za nedůležité; může snáze vyjevit specifika své osoby a své osobní situace

i) údaje získané individualizovanými nástroji jsou velmi dobrým východiskem pro cílené intervence

j) při opakovaném použití dovolují zachytit proměny ve struktuře, hierarchii i ve spokojenosti jedince, třeba s kvalitou vlastního života apod.

\section{Nevýhody individualizovaných nástrojů}

Až doposud jsme se zabývali pouze přednostmi individualizovaných metod pro diagnostiku kvality života. Tyto metody však mají i své nevýhody (modifikovaně podle Dijkers, 2003; O’Boyle et al., 2007; Martin et al., 2007):

a) mnohé $\mathrm{z}$ individualizovaných nástrojů jsou pro klienty pracné a časově náročné

b) některé $\mathrm{z}$ individualizovaných nástrojů vyžadují od klienta vyšší kognitivní schopnosti a rozvinutější komunikační dovednosti, čímž se zužuje okruh jejich použití

c) vyhodnocování údajů, které byly získány individualizovanými nástroji, je časově náročné a vyžaduje od odborníka speciální dovednosti a náročnějš́i postupy při zpracování (např. zpracování individuálních dat p-technikou faktorové analýzy)

d) některé z individualizovaných nástrojů neposkytují výsledky hned, zpracování dat je časově náročné, což se dá do jisté míry řešit počítačovými verzemi diagnostických nástrojů

e) proto některé individualizované nástroje zatím nedoznaly širšího použití; pouze je vyzkoušeli sami autoři, nebot' jde o velmi pracné postupy, které se hodí spíše pro výzkumné účely, než pro rutinní používání

f) individualizované nástroje jsou konstruovány pouze pro klienta samotného, nikoli pro lidi, kteří klienta znají a přicházejí s ním běžně do styku (členové rodiny, ošetřující personál apod.); to komplikuje zjištování kvality života u specifických populačních skupin

g) v této oblasti zatím neexistuje žádný „zlatý standard“, k němuž by bylo možnost vztáhnout údaje z nově konstruovaných individualizovaných diagnostických nástrojů a tím ověřit jejich validitu

h) tradiční postupy při hodnocení validity, které se osvědčily u běžných dotazníků, nejsou př́liš vhodné k měření validity individualizovaných nástrojů. 


\section{Literatura}

Barton, S., Morley, S., Bloxham, G. et al. (2005). Sentence Completion Test for Depression (SCD): An Idiographic Measure of Depressive Thinking. British Journal of Clinical Psychology. 44, 1, 29-46. ISSN 0144-6657.

Caldwell, T.L., Cervone, D., Rubin, L.H. (2008). Explaining Intra-Individual Variability in Social Behavior through Idiographic Assessment: The Case of Humor. Journal of Research in Personality. 42, 5, 12291245. ISSN 0092-6566.

Carr, A.J., Higginson, I.J. (2001). Measuring Quality of Life: Are Quality of Life Measures Patient Centered? British Medical Journal. 322, 1357-1360. ISSN 0959-8138.

Cervone, D., Caldwell, T.L., Orom, H. (2008) Beyond Person and Situation Effects: Intra-Individual Personality Architecture and Its Implications for the Study of Personality and Social Behavior. In Rhodewalt, F. (Ed.) Personality and Social Behavior (pp. 9-48). New York: Taylor and Francis. ISBN 13- 978-1- 84169-4504.

Claes, L., Van Mechelen, I., Vertommen, H. (2004). Assessment of Situation-Behavior Profiles and Their Guiding and Affective Processes: A Case Study from the Domain of Aggressive Behaviors. European Journal of Psychological Assessment. 20, 4, 216-226. ISSN 1015-5759.

Dazord, A. Astolf, F., Guisti, P. et al. (1998). Quality of Life Assessment in Psychiatry: the Subjective Quality of Life Profile (SQLP) - First Results of a New Instrument. Community Mental Health Journal. 34, 525535. ISSN 0010-3853.

Dazord, A., Mercier, C., Manificat, S. et al. (1995). Evaluation de la qualité de la vie: mise au point d'un instrument d'évaluation dans un context francophone. Revue de Européen de la Psychologie Apppliqueé. 45, 271-278. ISSN 1162-9088.

Dempster, M., Donnelly, M. (2000). How Well Do Elderly People Complete Individualised Quality of Life Measures: An Exploratory Study. Quality of Life Research. 9, 369-375. ISSN 0962-9343.

Dijkers, M.P. (2003). Individualization in Quality of Life Measurement: Instruments and Approaches. Archives of Physical Medicine and Rehabilitation. 84, 4, Suppl. 2, p. S3-S14. ISSN 0003-9993.

Dupuis, G.H., Tailler, M.C., Rivard, M.J. et al. (2001). Quality of Life Systemic Inventory (QLSI) : Sensitivity to Change and Psychometric Characteristics. Annals of Behavioral Medicine. 23 Suppl., p. S160. ISSN 0883-6612.

Haynes, S.N., Mumma, G.H., Pinson, C. (2009). Idiographic Assessment: Conceptual and Psychometric Foundations of Individualized Behavior Assessment. Clinical Psychology Review. 29, 2, 179-191. ISSN $0272-7358$.

Haynes, S.N., O’brien, W.H. (2000). Principles and Practice of Behavioral Assessment. New York: Kluwer Academic/Plenum Publishers. ISBN 0-306-46221-4.

Mareš, J. (2008). Individualizované zjištování kvality života. In Mareš, J. a kol. Kvalita života u dětí a dospívajícich III (pp. 69-109) Brno: MSD. ISBN 978-80-7392-076-0.

Martin, F., Camfield, L., Rodham, K. et al. (2007). Twelve Years' Experience with Patient Generated Index (PGI) of Quality of Life: A Graded Structure Review. Quality of Life Research. 16, 705-715. ISSN 09629343.

Mcfall, R.M. (2005). Theory and Utility - Key Themes in Evidence-Based Assessment: Comment on the Special Section. Psychological Assessment, 2005, vol. 17, no. 3, p. 312-323. ISSN 1040-3590.

Meyer, G.J., Finn, S.E., Eyde, L.D. et al. (2001). Psychological Testing and Psychological Assessment. American Psychologist. 56, 2, 128-165. ISSN 0003-006X.

Mumma, G.H. (2001). Increasing Accuracy in Clinical Decision-Making: Toward an Integration of NomotheticAggregate and Idiographic-Idiographic Approaches. The Behavior Therapist. 24, 1, 77-94.

O’boyle, C.A., Höfer, S., Ring, L. (2007). Individualized Quality of Life. In Fayers, P., Hays, R. (Eds.) Assessing Quality of Life in Clinical Trials $2^{\text {nd }}$ Edition (pp. 225-242). Oxford: Oxford University Press. ISBN 978-0-19-852769-5. 
Shoda, Y. Mischel, W., Wright, J. (1994). Intra-Individual Stability in the Organization and Patterns of Behavior: Incorporating Psychological Situation into the Idiographic Analysis of Personality. Journal of Personality and Social Psychology. 67, 4, 674-687. ISSN 0022-3514.

Tashakkori, A., Teddlie, C. (Eds.) (2003). Handbook of Mixed Methods in Social and Behavioral Research. Thousand Oaks: Sage Publication. ISBN 0-7619-2073-0.

Windelband, W. „Štrasburský rektorský prejav 1894،“ In Hruškovský, I., Zigo, M. (Eds.). (1967). Antológia $z$ diel filozofov. Pozitivizmus, voluntarizmus, novokantovstvo (pp. 524 - 537). Bratislava: Vydavatel'stvo politickej literatúry.

Prof. PhDr. Jiř́i Mareš, CSc.

Lékařská fakulta UK

Ústav sociálního lékařství

Šimkova 870

50038 Hradec Králové

e-mail: mares@lfhk.cuni.cz 